\title{
BRAZILIAN CONTEMPORARY POETRY: AN OVERVIEW
}

\section{POESIA BRASILEIRA CONTEMPORÂNEA: UM PANORAMA}

Viviana Bosi ${ }^{1}$

\begin{abstract}
Resumo: Embora possa parecer uma tarefa impossível o oferecimento de um panorama da poesia brasileira contemporânea, discutiremos uma seleção de poetas que possivelmente exemplifica as correntes mais significativas. Começamos com uma breve apresentação de quarto autores bem conceituados cujos trabalhos representam as principais correntes poéticas: Augusto de Campos, Francisco Alvim, Armando Freitas Filho e Adélia Prado. Depois comentaremos passagens de alguns poetas importantes mais jovens, cujas obras abrangem diferentes tons e estilos, desde a mitologia simbólica indígena até testemunhos crus ou irônicos sobre a vida na cidade grande, desde a intimidade lírica melodiosa até uma perspectiva mais social. Para a segunda parte deste artigo, escolhemos Paulo Henriques Britto, Josely Vianna Baptista, Ricardo Aleixo, Carlito Azevedo, Eucanaã Ferraz and Ana Martins Marques. Esperamos que esta seleção preliminar possa despertar o interesse de futuros leitores para a enorme variedade e riqueza da poesia brasileira.
\end{abstract}

Palavras-chave: Brasil, poesia contemporânea, correntes relevantes.

\begin{abstract}
Although it may seem an impossible task to offer a panorama of contemporary Brazilian poetry, we will discuss a selection of poets who possibly epitomize the most significant current trends. We start with a brief presentation of four well-regarded authors whose works represent major poetic currents: Augusto de Campos, Francisco Alvim, Armando Freitas Filho and Adélia Prado. We then comment on excerpts from a few important younger poets, whose works embrace several different tones and styles, from indigenous symbolic mythology to crude or ironic testimonials of life in the big city, from melodious lyrical intimacy to a more social perspective. For the second part of this article, we have chosen Paulo Henriques Britto, Josely Vianna Baptista, Ricardo Aleixo, Carlito Azevedo, Eucanaã Ferraz and Ana Martins Marques. We hope this preliminary selection may awaken the interest of future readers to the enormous variety and richness of Brazilian poetry.
\end{abstract}

Keywords: Brazil, contemporary poetry, relevant trends.

It would be foolhardy to attempt to provide an overview of the enormous plurality of contemporary poetic creation in a continental country as racially, ethnically and culturally diverse as Brazil. We can't hope to cover even a barely generous portion of what is being printed today. While the best-known poets in urban centers are those published by the major houses, part of the poetic variety of Brazil derives from deeply embedded relationships with popular culture. Recent years saw the vigorous dissemination of oft-oral poetry emerging from quite different realities - of the outskirts of the country's largest cities, for instance, or of the veteran improvisers who traditionally ad-lib verses and songs in the hinterlands. The Internet has also helped to call attention to countless poets who are starting to publish on blogs and e-zines, exchanging their verses and establishing far-reaching contact networks.

Brazilian popular music is likewise acknowledged for the sophistication of its lyrics. Chico Buarque and Caetano Veloso, now the elder generation, continue to compose songs

\footnotetext{
${ }^{1}$ Universidade de São Paulo - USP, São Paulo, São Paulo, Brasil; https://orcid.org/0000-0002-0217-494X; vivianab@usp.br
} 
notable for the richness of poetic nuances. Influenced by a tradition that goes back at least to Vinícius de Moraes, other artists move about between more bookish poetry and the wider universe of mass entertainment.

In addition to the impossibility of covering the production of the different regions of Brazil, which rarely ever reach the mainstream media or attract academic criticism, there are also restraints imposed by taste, a side effect of our upbringing. Therefore, rather insufficiently, we have modestly undertaken this brief presentation as no more than an appetizer for those interested in the subject.

To avoid coming up with some sort of anodyne catalog, we will address only a handful of poets, preferring the injustice of silence to empty and exhausting name-dropping.

We will first mention four authors, four older poets with a consolidated body of work: Augusto de Campos, Francisco Alvim, Armando Freitas Filho and Adélia Prado. Each corresponds to a unique sphere of influence.

Augusto de Campos (São Paulo, b.1931) is the greatest living representative of Concrete Poetry, the avant-garde movement of the mid-1950s with a large lineage both in literature and in popular music. Celebrated for visual experimentation, Augusto de Campos' poetic work is renowned for its nominal conciseness, wordplay, critical attitude. The formal innovations, which allude to constructivist aesthetics, give the poems a geometric aspect that resembles the grids of abstract painting.

Campos' more recent works, however, are reflections on the exhaustion or depletion of the cycle of progressive hopes that prevailed between the 1950s and 1960s, the heyday of the Concrete movement. Thus, although partially retaining the formal procedures of what is known as "verbi-voco-visual poetry," the tone of his compositions today evokes another type of relationship with the present, as can be seen in the following poem:

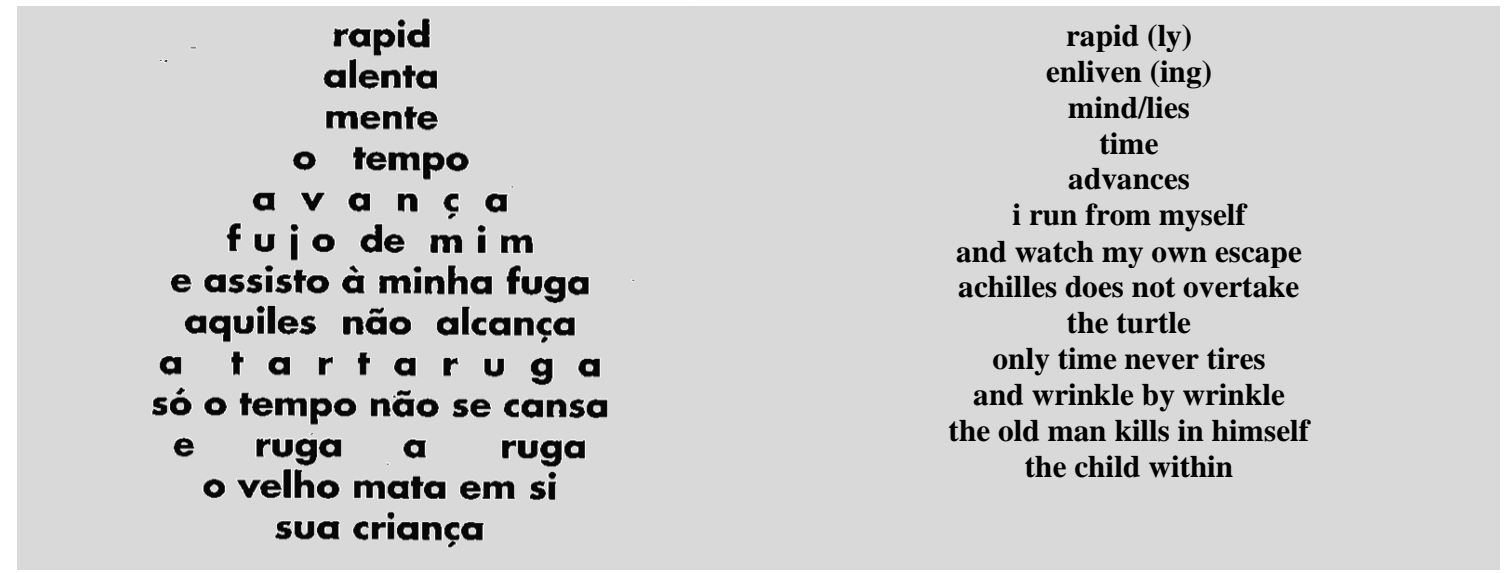

Augusto de Campos. Não, 2003.

True to the concept that a poem's structure should reveal its content, the passage of time is depicted here as a drop that reiterates the impossibility of progressing towards a positive outcome. The variable spacing between letters and words seeks to represent the rhythm of the futile escape that cannot evade the direction of death. This is, perhaps, the main change we detect in Augusto de Campos' work of recent decades: the optimistic belief in the future that energized the early manifestos of Concrete Poetry (published in the mid-1950s and early 1960s by the group to which the author belonged) changed into skepticism toward the possibility of 
social evolution. The horizon of expectations withered. His worldview alternates between resignation and pessimism, which translates into circular-looking poems, denouncing the lack of a way out.

A poet from a different strain, Francisco Alvim (Araxá, Minas Gerais, b.1938) descends from an atmosphere closer to another stream of Modernism. In him, we recognize vestiges of Oswald de Andrade and his "joke poems," as well as a kindred spirit to Carlos Drummond de Andrade's disenchanted sense of humor. Known for the poignancy with which he unveils social prejudice, he alternates lyricism and veiled criticism, lending his ironical voice to typical Brazilian characters. Sometimes his verses are elliptical, understandable only to those who know Brazilian society well, such as the emblematic:

Mas

é limpinha

\section{But}

she's nice and clean

Francisco Alvim. Elefante, 2000.

A one-line poem, the title itself alludes obliquely to all sorts of prejudices against a poor, underling, possibly black woman. In Portuguese, the diminutive adjective limpinha both attenuates and reveals, in a single stroke, the nuances of patriarchal affection.

Here are some other minimalist samples:

Selas

Experimentei

não reagiu

\section{Saddles}

I tried

No reaction
Parque

É bom

mas é muito misturado

\section{Park}

It's pleasant

but very mixed

\section{Argumento}

Mas se todos fazem

\section{Argument}

But if everyone does it

Francisco Alvim. Elefante, 2000.

The poet replicates everyday words that reflect the class contradictions and corrupt cynicism of part of Brazilian society. In the 1970s, many of his poems echoed sinister voices of power: 
Autoridade

Onde a lei não cria obstáculos coloco labirintos
Authority

Where the law creates no obstacles I place mazes

Francisco Alvim. Dia sim dia não, 1978.

But this is not the only mood in Francisco Alvim's work. A considerable part of his poetry is intensely lyrical. Images of the permeability between the joyful individual and nature brightly invade his verses, as can be seen here:

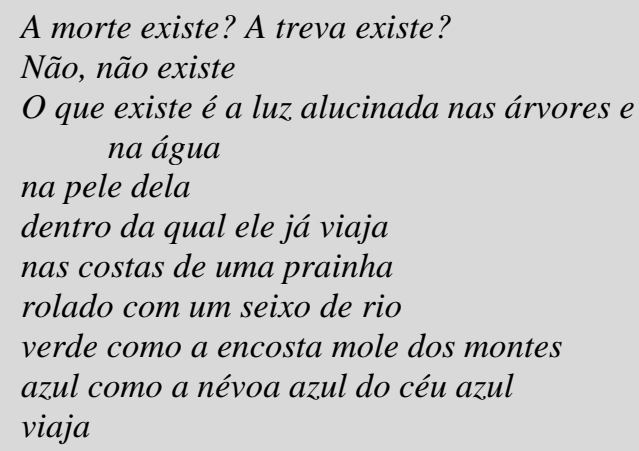

\author{
Does death exist? Does darkness exist? \\ No, it does not \\ What exists is hallucinating light on trees and \\ in water \\ on her skin \\ within which he already travels \\ on the slopes of a little beach \\ rolled up with a river pebble \\ green as the mellow hillsides \\ blue as the blue mist of the blue sky \\ travels
}

Francisco Alvim. Excerpt from “Coluna,” Lago, montanha, 1981.

A blue and green idyll abides by the poet's loving desire, as a utopian counterpoint to the darkness of human society.

The poet Armando Freitas Filho (Rio de Janeiro, b.1940) adds to the poetic lineage of the ubiquitous Drummond and João Cabral de Melo Neto (acknowledged by many as the greatest Brazilian poets of the $20^{\text {th }}$ century), as an important inspiration, the works of Ferreira Gullar (recently deceased) as well as the production of the so-called marginal or underground poets (among whom we must underscore, as a recurring influence, the fleeting star of Ana Cristina Cesar). The inner vitals of existential experience, the raw accounts of everyday living, the challenges of exile (inner or even real, as in the case of Gullar and so many others, persecuted by the dictatorship from the early 1960s to the late 1970s), reappear vividly in his vast work. Freitas Filho is a poet obsessed with a harsh and rough relationship with writing, as evinced in the following poem:

\section{6}

Escrever é arriscar tigres

ou algo que arranhe, ralando

o peito na borda do limite

\section{6}

To write is to risk tigers

or something that scratches, grating

the breast on the edge of the limit 


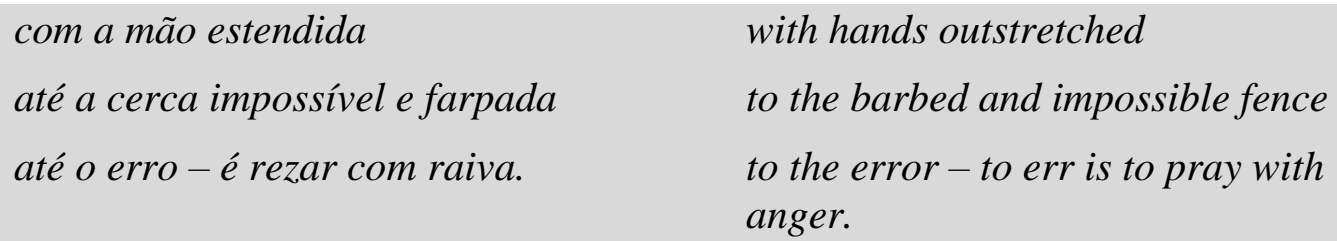

14 VIII 2001

14 VIII 2001

Armando Freitas Filho. Numeral/ Nominal, 2003.

In English, the guttural sound of the " $r$ " that pervades the poem is lost, tapering therefore the sense of going against the grain and insurmountable obstacles that is characteristic of Freitas Filho's verses. Hurling oneself against the wall of things, throwing oneself from a trampoline toward risk, are recurring images of his poetics. The insufficiency of words, coupled with an urgency to express himself, almost as a howl (albeit a calculated howl), recurs as unsolvable anguish in much of his work.

Finally, to round off this quartet, we introduce Adélia Prado (Divinópolis, Minas Gerais, b.1935), who began publishing late in her life. By and large, she turns her eyes to portraits of the ordinary day-to-day in a small town, observing family life, the neighborhood, the church, taking a sharp look into what is seemingly banal, which in her poetry is pierced by rather unconventional religious questionings. Her poems about everyday life elevate the ordinary without removing its simplicity:

$\begin{array}{ll}\text { Ensinamento } & \text { Teaching } \\ \text { Minha mãe achava estudo } & \text { My mother thought study was } \\ \text { a coisa mais fina do mundo. } & \text { the finest thing in the world. } \\ \text { Não é. } & \text { It is not. } \\ \text { A coisa mais fina do mundo é o sentimento. } & \text { The finest thing in the world is feeling. } \\ \text { Aquele dia de noite, o pai fazendo serão, } & \text { That day at night, father moonlighting, } \\ \text { ela falou comigo: } & \text { she said to me: } \\ \text { 'coitado, até essa hora no serviço pesado'. } & \text { "poor guy, so late and still working so hard." } \\ \text { Arrumou pão e café, deixou tacho no fogo } & \text { She laid out bread and coffee, left the pan on the } \\ \quad \text { com água quente. } & \text { fire with hot water. } \\ \text { Não me falou em amor. } & \text { She didn't speak to me about love. } \\ \text { Essa palavra de luxo. } & \text { That luxury word. }\end{array}$

Adélia Prado. Bagagem, 1976.

Her poems often evoke a prosaic atmosphere, as if they were unpretentious small talk. The transfiguration takes place through everyday objects and sensations: 


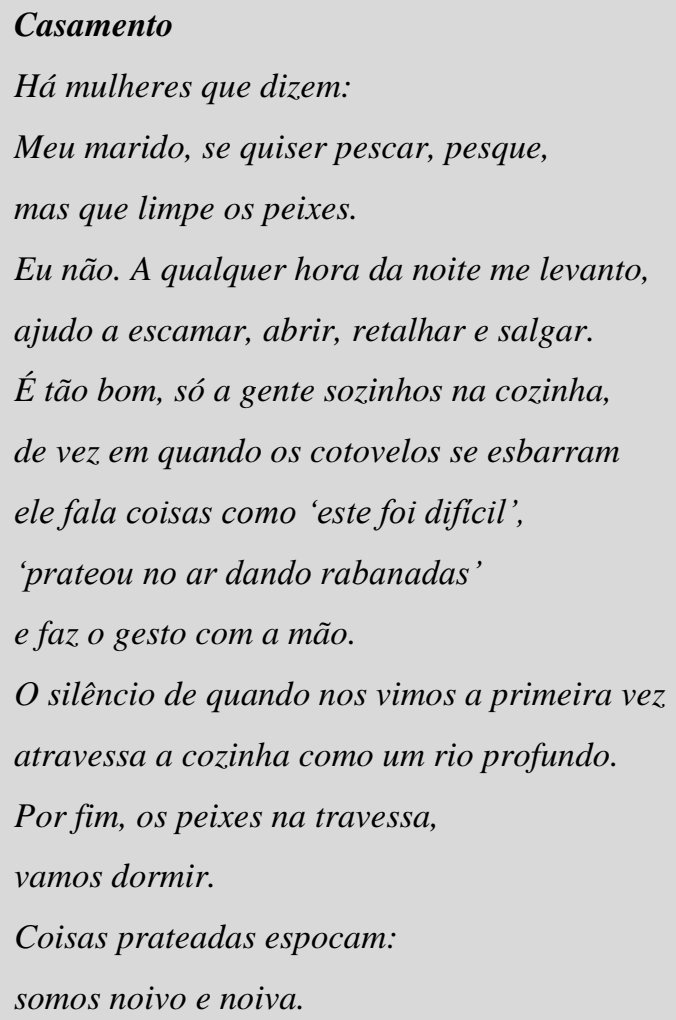

\section{Marriage}

There are women who say:

My husband, if you want to fish, fish,

but clean the fish.

Not me. At any time of night I'll get up,

help to scale, open up, shred and salt.

It's so nice, just us alone in the kitchen,

once in a while our elbows bump

he says things like "this was a tough one,"

"silvered in the air striking its tail"

and makes a gesture with his hands.

The silence of when we first met

flows through the kitchen like a deep river.

At last, the fishes on the platter,

we go to sleep.

Silver things pop and burst:

we are groom and bride.

Adélia Prado. Terra de Santa Cruz, 1981.

In both poems, coincidentally perhaps, the lyrical subject contradicts what commonplaceness has taught her and silently asserts another truth. Both poems take place in a kitchen, a predominantly female environment, where love is confirmed in gestures more than words.

$* * * * * * *$

We would now like to highlight, in this brief overview, some poets from younger generations, and point out a few relevant trends. It cannot be said that there are cohesive poetic movements today. Each poet seems to establish multiple affiliations, spawned by their own questionings. Thus, more than the potential aesthetic orientations of groups, we will be mapping out irradiating singularities.

An important contemporary current reflects on the impossibility of expression in our time. The feeling of having arrived late is a constant in modern-day poetry. Paulo Henriques Britto (Rio de Janeiro, b.1951), poet and eminent translator, exquisitely cultivates various poetic forms, might well be a representative of this proclivity. His poetry is often self-ironic; avoiding any belief in authentic subjective expression, since, as he says, everything has already been said. In one poem, he compares himself to the panda, which has difficulty digesting bamboo, yet nevertheless insists on eating it as its favorite food. Even as Britto recognizes the uselessness of continuing to write, he cannot avoid the need to do so. 


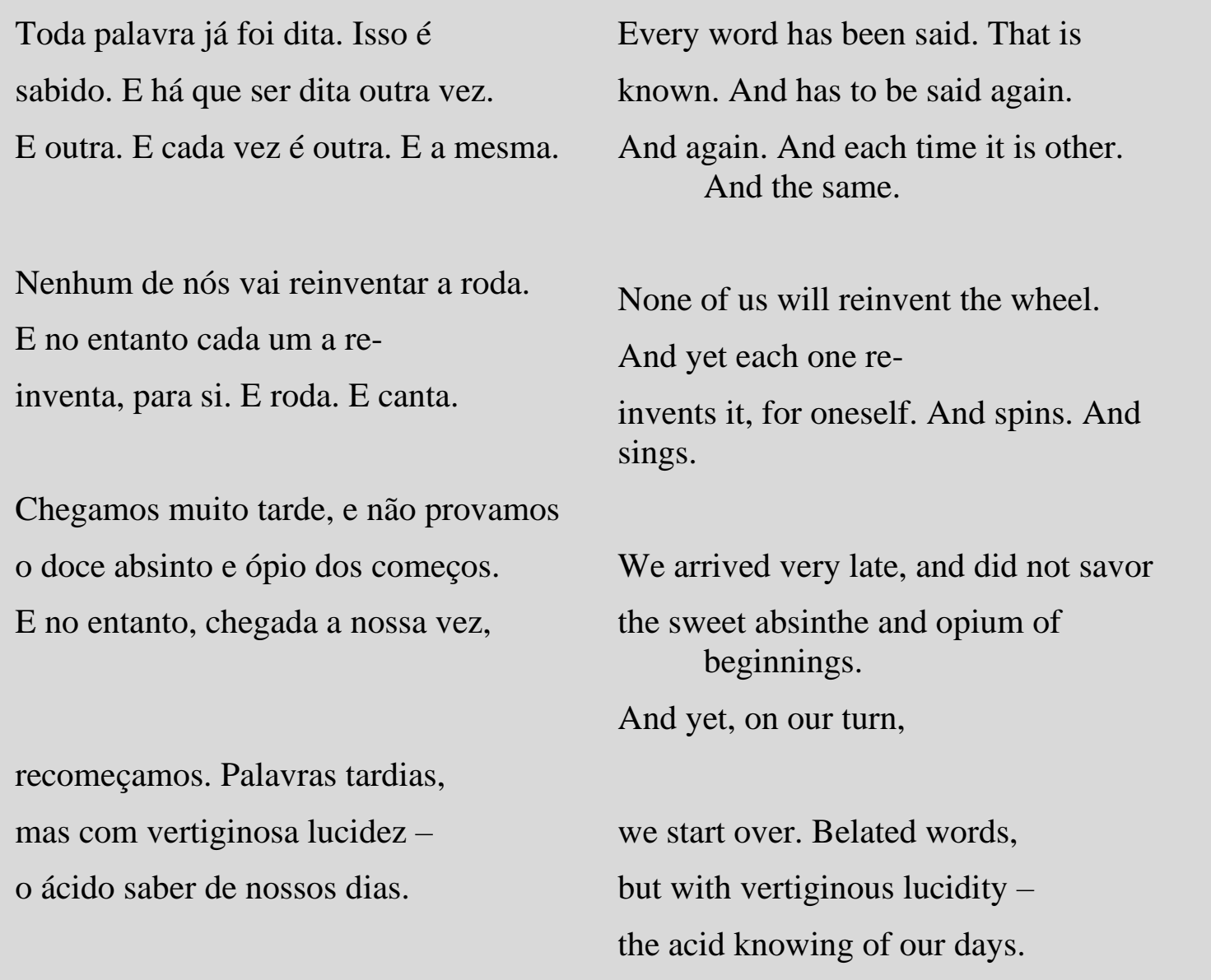

Paulo Henriques Britto. “Crepuscular,” 5, Tarde, 2007.

Begotten under the influence of the visuality and conciseness of concrete poetry, the work of Josely Vianna Baptista (Curitiba, b.1957) created a truly diverse space for poetic expression. Her poems include images from the cosmology of the Guarani people, whose chants she also translated:

$\begin{array}{ll}\text { em busca de outro sol } & \text { in search of another sun } \\ \text { pode alguém se perder } & \text { may one get lost } \\ \text { abandonando o humano } & \text { abandoning the human } \\ \text { para encontrar seu deus } & \text { to find one's god } \\ \text { - o mesmo que ao nascer } & \text { - the same who at birth } \\ \text { deu-lhe um nome secreto } & \text { gave a secret name } \\ \text { de sua divindade } & \text { of its divinity } \\ \text { perfeito e repleto. } & \text { perfect and replete. }\end{array}$

Josely Vianna Baptista. Stanza of "guirá ñandu,” Roça barroca, 2011. 
There has been in recent years an intense movement of creative dialogue with both Amerindian mythologies and the diverse cultures of African origin, which fertilize Brazilian poetry with images and rhythms with perspectives discrepant from the so-called western modernity, and expand the way we see individuals and contemporary life. Afro-descendant poets, in particular, proclaim their identity, denouncing through poetry their historical awareness of discrimination. The poetic production of Ricardo Aleixo (Belo Horizonte, b.1960) is one of the most powerful in this context. Known for the performance-like quality of his presentations, his work varies in form and subject, ranging from political engagement, love lyricism, urban questionings and family backgrounds to metalanguage. Thus, it would be reductive to limit his work to a single theme. In the poem below, Aleixo seems to refer to both an African deity and a black artist, dancer or folk composer:

$\begin{array}{ll}\begin{array}{l}\text { inteligência retinta } \\ \text { elegância }\end{array} & \begin{array}{l}\text { true-black intelligence } \\ \text { elegance }\end{array} \\ \text { pelintra } & \text { guttersnipe } \\ \text { negrícia felina } & \text { feline blackitude } \\ \text { malícia } & \text { malice } \\ \text { de bicho totêmico } & \text { of totemic critter } \\ \text { novo } & \text { new } \\ \text { antiquíssimo griô afro- } & \text { age-old Afro- } \\ \text { futurista } & \text { futuristic griot } \\ \text { todo mandinga } & \text { all hoodoo } \\ \text { \&ginga } & \text { \&knack } \\ \text { e o mundo } & \text { and the world } \\ \text { inteiro guardado } & \text { wholly kept } \\ \text { num passo ancestre } & \text { in an ancestral step } \\ \text { mestressala } & \text { magnificent } \\ \text { maravilha } & \text { mestressala } \\ \text { contemporânea que vai } & \text { a contemporary who goes } \\ \text { desde o largo do Estácio } & \text { from Estácio square } \\ \text { até a mais alta estrela } & \text { to the highest star } \\ \text { que brilha } & \text { that shines } \\ \text { sobre o atlântico } & \text { over the atlantic } \\ \text { negro oceano } & \text { black ocean } \\ \text { quando um dos muitos } & \text { when one of his } \\ \text { nomes dele é ébano } & \text { many names is ebony } \\ & \end{array}$

Ricardo Aleixo. "Um dos muitos nomes dele," Pesado demais para a ventania: antologia poética, 2018. 
The use of terms sourced in Africa (and already embedded into Portuguese), together with the syncopated measure, generates a special sound effect, reminiscent of the beat of the samba steps.

In another dimension, Carlito Azevedo (Rio de Janeiro, b.1961) has been experimenting with various timbres, oscillating from verse to prose, to meditate on the human condition from a global viewpoint (including immigrants, foreigners, travel situations). Some poems resemble dialogue sequences in which two characters meet for a walk and interweave their impressions on life, the landscape, the world situation. As they walk, they watch the passersby, reflect on existence, contemplate the sky and the city. The contrast between bright opening clouds and a dog trying to cross the avenue, whose eyes reflect the headlights of cars, leads the poet to pause to think about the possible relationships between things, even if he does not come up with an answer, except for a fleeting but powerful experience of beauty:

$\begin{array}{ll}\text { “como não tenho } & \text { "as i no longer } \\ \text { mais questão alguma } & \text { have issues with } \\ \text { com a metafísica, eu } & \text { metaphysics, i } \\ \text { não fico esperando por } & \text { don’t expect that } \\ \text { alguma presença para } & \text { some presence will } \\ \text { experimentar o que } & \text { experiment what } \\ \text { experimento, experimento, } & \text { i experiment, experiment, } \\ \text { todos os dias." } & \text { every day." }\end{array}$

Carlito Azevedo. “O tubo,” Monodrama, 2009.

Another poet with a complex body of work is Eucanaã Ferraz (Rio de Janeiro, b.1961). We consider his poetry the most varied and comprehensive of all that has been published recently. Trying to summarize it in a few sentences, therefore, can only lead to failure. The difficulty of defining it stems from the ampleness of tones and themes that inhabit his books. I have chosen, from a series of poems that sing the affairs of the heart and lament their end, these excerpts with monosyllabic titles:

Ao

Livres irmãos apenas dos poemas em noites sem explicação ou limite nós nos deitávamos sobre uma única e mesma corda desdobrada sobre a morte e não morríamos porque na inocência éramos fortes.

Mas as manhãs eram lobos transparentes que rentes ao osso vinham nos tingir de seu azul agourento.
To

Free brothers only from poems on nights with no explanation or limit we would lay on a single and same rope unfolded over death and we didn't die because in innocence we were strong.

But mornings were transparent wolves that flush to the bone came to dye us with their ominous blue. 
Estamos bem assim, não acha? Entre nós um jardim de areia arde sob o sol isento. É o que está certo, reguemos a ardósia de nosso breve deserto. Nenhuns amores nenhumas dores - as sementes lá no alto e nenhuma escada. Se um desejo voasse por perto, fazíamos bem de evitar os olhos e por a mão nos bolsos. O vento, escuta, é mais feliz nos cabelos das estátuas, assim sossegadas.

$[\ldots]$

\section{$\grave{A}$}

Legítima estupidez a minha (a dos que amam):

deixar o mel à tona.

Melancolia previsível que agora moscas o comam. $[\ldots]$

\section{Under}

We're fine now, don't you think? Between us a sand garden burns under the insouciant sun. This is what is right, let's water the slate of our brief desert. No loves no pains - the seeds up high and no stairs. If a wish flew nearby, we did well to avoid the eyes and pocket our hands. The wind, listen, is happier in the hairs of statues, thus quieted.

[...]

To

Legitimate stupidity of mine (of those who love):

to leave the honey uncovered.

Predictable melancholy that now flies would eat it.

Eucanaã Ferraz. “Memórias póstumas,” Escuta, 2015.

In the sequence of poems above, the lyrical subject equates failed love to sunken ships whose wreckages lodge in one's body - which sinks, injured, risking death. Happiness lasts but so briefly, it is almost illusory: "the two of us / under the sky of a starless hotel," and soon fades away: "I couldn't save one single instant / of our skin breaking apart." The pain of the beheaded, in the manner of St. John the Baptist and the soulless Salome, may take on a sarcastic tone: "But you / you did not even know the difference / between a heart and a meatball" - a heart, incidentally, "that fell upon our feet." The destruction of love ultimately leads to dreariness and immobility. But this caustic disposition, when it concerns human relationships, mingles with exaltation to beauty in nature and in loved ones with highly intense imagery.

One of the most trenchant drifts of current poetry is the one that scrutinizes everyday life in big cities, often addressing marginalized characters who roam degraded urban landscapes. Through the experience of shock, with sarcasm and horror, compassion and irony, the lyrical subject embodies the voice of the dispossessed. I turn now to Fabio Weintraub (b.1967), poet from São Paulo, who evokes in the verses below a pathetic homeless man, driven mad amidst the traffic:

$\begin{array}{ll}\text { Até debaixo d'água! } & \text { Even underwater! } \\ \text { Sou homem até debaixo d'água! } & \text { I'm a man even underwater! } \\ \text { grita o vulto enrolado } & \text { shouts the looming figure curled } \\ \text { em feltro e revolta } & \text { in felt and revolt } \\ \text { papelão e delírio } & \text { cardboard and delirium }\end{array}$


A que água se referia?

Quem o obrigara a andar sobre a prancha?

Por quanto tempo já

brigava com a onda

de carro e fuligem?

O náufrago se aferra

aos tesouros da hombridade

sem arca, sem mapa

nem garrafa que conduza

até a ilha mais próxima

sua palavra afogada
What water was he referring to?

Who had made him walk over the plank?

For how long had he

fought with the wave

of car and soot?

The castaway holds on

to the treasures of manhood

no coffer, no map

no bottle that leads

to the nearest island

his drowned word

Fabio Weintraub. First stanzas of "Náufrago," Novo endereço, 2002.

A human being transformed into an excretion tries to assert himself amid the indifference of those who pass him by. He proclaims his indisputable virility while his voice is drowned out by the noise of traffic, like a shipwrecked navigator.

Ana Martins Marques (Belo Horizonte, b.1977) often thematizes the role of poetry, questioning the relationship between word and world:

$$
\text { na cachoeira }
$$

Quando o corpo finalmente encontra lugar

na pedra quente

abre

um livro mineral

com a atenção dividida entre o céu e as letras,

que o sol ofusca,

e a página torna-se branca

como a água.

\section{in the waterfall}

When the body finally finds a place

upon the hot stone

it opens

a mineral book

with attention divided between the sky and the letters,

that the sun obfuscates,

and the page turns white

like water.

Ana Martins Marques. “6 posições para ler,” A vida submarina, 2009. 
In her poems, house objects (tables, chairs, beds, pots, cups) seem to retain the memory of the lonely home dwellers, awaiting love and its disillusionments. The lyrical subject lingers on them, as if they were metaphors of time:

$\begin{array}{ll}\text { Água estancada } & \text { Stagnant water } \\ \text { e exata } & \text { and exact } \\ \text { como um lago } & \text { like a lake } \\ \text { com quatro cantos. } & \text { with four corners. } \\ \text { Devolve-nos o rosto impensado. } & \text { Gives us back the unmindful face. } \\ \text { Nunca morre. } & \text { Never dies. } \\ \begin{array}{l}\text { Mas repara: vai envelhecendo } \\ \text { conosco. }\end{array} & \text { But notice: it gets old with us. }\end{array}$

Ana Martins Marques. "Espelho,” A vida submarina, 2009.

$* * * * * * *$

Might there be something in common between these poets - what one used to call the spirit of the times?

It would seem that all of them fiercely struggle between lyrical puissance (which, by conferring a certain porosity vis-à-vis the world, enables metaphorical correspondences) and critical sharpness (amidst irony, self-reflexivity, inquiry). This double movement, varying in degree and type of relationship in each poem, creates an impression of distrust in the possibility of a full encounter with one's self, with others and with life itself. Having somehow relinquished their crucial role as seers, prophets and augurs, poets nonetheless urge us to see, feel, suffer and hear the sounds of submerged words stifled under a façade of reality, and adamantly insist on paying attention to what can barely be glimpsed, being essentially faithful to the true world.

\section{WORKS CITED:}

ALEIXO, Ricardo. Pesado demais para a ventania: antologia poética. São Paulo: Todavia, 2018.

ALVIM, Francisco (com AUGUSTO, Eudoro). Dia sim dia não. Brasília: Mão no bolso, 1978. In: ALVIM, Francisco. Poemas (1968-2000). São Paulo: Cosac Naify; Rio de Janeiro: 7 Letras, 2004.

ALVIM, Francisco. Elefante. São Paulo: Companhia das Letras, 2000.

ALVIM, Francisco. Lago, montanha. Rio de Janeiro: Janex, 1981. In: ALVIM, Francisco. Poemas (1968-2000). São Paulo: Cosac Naify; Rio de Janeiro: 7 Letras, 2004.

AZEVEDO, Carlito. Monodrama. Rio de Janeiro: 7 Letras, 2009.

BAPTISTA, Josely Vianna. Roça barroca. São Paulo: Cosac Naify, 2011.

BRITTO, Paulo Henriques. Tarde. São Paulo: Companhia das Letras, 2007.

CAMPOS, Augusto de. Não. São Paulo: Perspectiva, 2003.

FERRAZ, Eucanaã. Escuta. São Paulo: Companhia das Letras, 2015.

FREITAS FILHO, Armando. Numeral/ Nominal. In: FREITAS FILHO, Armando. Máquina de escrever. Poesia reunida e revista. Rio de Janeiro: Nova Fronteira, 2003.

MARQUES, Ana Martins. A vida submarina. Belo Horizonte: Scriptum, 2009.

PRADO, Adélia. Bagagem. Rio de Janeiro: Imago, 1976. 
PRADO, Adélia. Terra de Santa Cruz. Rio de Janeiro: Nova Fronteira, 1981.

WEINTRAUB, Fabio. Novo endereço. São Paulo: Nankin; Juiz de Fora: FUNALFA, 2002.

Viviana Bosi é Professora da Universidade de São Paulo - USP. Mais informações em http://lattes.cnpq.br/7702939346364920

Submetido em 21/04/2020

Aprovado em 25/06/2020 